\title{
Statin Therapy as Primary Prevention in Exercising Adults: Best Evidence for Avoiding Myalgia
}

\author{
N. John Bosomworth, MD, CCFP
}

Introduction: This review aims to determine whether active adults who begin statins and develop myalgia reduce or stop activity to become less symptomatic. If this occurs, strategies to mitigate symptoms are explored. Should these strategies fail, the question of whether exercise is an adequate alternative to statin therapy is addressed.

Methods: PubMed, Google Scholar, and the Cochrane Database were searched with keywords designed to retrieve information on statin myopathy in exercising adults.

Results: Statins are well tolerated by most people who exercise; however, caution is warranted in those who exercise at high levels, in the elderly, and in those receiving high-dose therapy. Several strategies improve statin tolerance while maintaining exercise levels, based on low-quality evidence. If statins are not tolerated, a continuing physical activity program can provide equivalent or superior cardiometabolic protection.

Conclusions: Statins may occasionally present a barrier to physical activity. A number of strategies exist that can reduce the risk of myopathy. If a choice between exercise and statins becomes necessary, exercise provides equal benefit in terms of cardiovascular protection and superior mortality reduction, with improved quality of life. (J Am Board Fam Med 2016;29:727-740.)

Keywords: Aged, Exercise, Hydroxymethylglutaryl-CoA Reductase Inhibitors, Muscles, Muscular Diseases, Myalgia, PubMed, Quality of Life

Wider indications, lower treatment thresholds, and higher dosing ranges for statin therapy in the primary prevention of cardiovascular disease (CVD) have been common trends in North American guidelines for lipid management since $2012 .{ }^{1-3} \mathrm{Ad}-$ herence to the American College of Cardiology and American Heart Association guidelines would result in treatment recommendations based on age alone: all white men aged 63 to 75 years and all white women aged 71 to 75 years, with otherwise optimal risk factors. ${ }^{4}$ Several meta-analyses have suggested event reduction beyond age $75 .{ }^{5-7}$ Rela-

This article was externally peer reviewed.

Submitted 1 March 2016; revised 7 June 2016; accepted 13 June 2016.

From the Department of Family Practice, Faculty of Medicine, University of British Columbia, Vancouver, BC, Canada.

Funding: none.

Conflict of interest: none declared.

Corresponding author: N. John Bosomworth, MD, CCFP, Department of Family Practice, Faculty of Medicine, University of British Columbia, 3413 Forsyth Dr., Penticton, British Columbia V2A 8Z2, Canada (E-mail: jbosomworth@ gmail.com). tive event reduction is thought to be at least as large in patients at low risk for CVD as it is for those at high risk, admittedly with much larger numbers needed to treat. Although individuals without known CVD are at lower absolute risk, nearly half of vascular events may occur in this population. ${ }^{5}$

The demonstrated effectiveness of statins in primary prevention, together with the increased availability of generic high-potency formulations, makes preventive therapy attractive for large numbers of people on a population basis. In return for a cardiovascular benefit to 1 person in a low-risk population, many people will be treated who could not possibly benefit. ${ }^{8}$ For this reason, the adverse effects of a statin intervention must be kept extremely low, as potential harm remains the same for the numerous people who receive no treatment advantage. ${ }^{2,9,10}$ Unfortunately, the adverse effects of statins have not been studied and reported as systematically as the benefits. ${ }^{11}$

Although the vast majority of the North American population is sedentary, ${ }^{12,13}$ significant numbers undertake physical activity (PA) on a regular 
basis. There is increasing participation in endurance $^{14}$ and ultraendurance sports, ${ }^{15}$ with ongoing increased participation by women. ${ }^{14}$ Runners $\geq 40$ years old now constitute almost half of marathon participants in the United States. ${ }^{14}$ Others simply remain active as a health and lifestyle choice. Among the known triggers for statin myopathy, exercise is most frequently associated with morbidity. ${ }^{16-18}$ Because PA is a potent factor in reducing both cardiovascular events ${ }^{19}$ and mortality, ${ }^{20}$ it is important that we not interfere with the implementation of an effective lifestyle option by introducing a drug intervention that may impair the ability to exercise. At the same time, there is clear observational evidence for the benefits of statin therapy, even at high levels of exercise, ${ }^{21}$ so a combination of lifestyle and drug interventions is optimal if this conforms to patient preference.

The objectives of this review are 3 -fold:

1. To determine whether statin administration increases the risk of muscle symptoms and leads to reductions in PA among exercising people without known CVD

2. To determine what might be done to mitigate any increase in symptoms to allow the increased protection against CVD provided by statins

3. If there are intolerable symptoms despite attempts at mitigation, to determine whether exercise alone can provide protection against CVD and mortality protection comparable to the known and proven benefits of statin therapy.

\section{Methods}

A narrative review was undertaken to determine the influence of statin therapy on muscle symptoms and activity levels among exercising adults in primary prevention. Further information was accumulated to gather data on symptom mitigation and therapeutic alternatives as stated in the objectives listed above.

\section{Search Strategy}

PubMed was originally searched for articles available in English using the search keywords statin* AND (muscle OR myopathy) AND (exercise OR "physical activity" OR fitness) NOT (rebabilitation OR cancer). The exclusion terms were to limit the retrieval of cardiac rehabilitation studies that address secondary prevention and cancer, which are outside the scope of this inquiry. Bibliographies of relevant articles were searched for additional references. The same search terms were used in similar queries of the Cochrane Database and Google Scholar. Similar PubMed searches were made for meta-analyses relating to health outcomes for either statin therapy or the grouping of exercise keywords. Outcomes were entered as mortality OR "cardiovascular disease" OR "cardiovascular events." These articles were used to evaluate, where possible, the relative effects of exercise and statin therapy on mortality or cardiovascular outcomes.

\section{Study Selection}

The Strength of Recommendations Taxonomy ${ }^{22}$ was used to evaluate recommendations and study quality (Table 1). In comparing individual benefits of statins and exercise, level 1 evidence was selected for trials related to statins, as numerous randomized controlled trials (RCTs), systematic reviews, and meta-analyses were available. The most reliable evidence for exercise outcomes was from prospective cohort studies because of constraints imposed by problems with blinding, allocation concealment, and adherence. Exercise studies therefore included level 2 and 3 evidence. Articles on secondary prevention, animal studies, and studies of populations with cancer or chronic disease were excluded.

\section{Results}

\section{Pathophysiology}

Statin effects on muscle are the subject of some controversy. Terminology varies among clinical advisories, ${ }^{23-25}$ and the American Heart Association/American College of Cardiology classification is used in this discussion, where myositis implies inflammation marked by an increase in creatine kinase (CK) and myopatby refers to any muscle event (Table 2).

Unaccustomed exercise induces muscle injury, with myalgia and CK concentrations peaking 2 to 3 days after the activity. There is evidence of increased inflammatory response following exercise, with the release of proteolytic enzymes and reactive oxygen species in preparation for tissue regeneration. This cycle of damage and repair is considerably blunted by repeated bouts of similar exercise. ${ }^{26}$

The mechanism for muscle toxicity associated with statin therapy is not well understood. A blinded crossover study ${ }^{27}$ established that symp- 
Table 1. Strength of Recommendation Taxonomy

\begin{tabular}{ll}
\hline Strength of Recommendation & \multicolumn{1}{c}{ Definition } \\
\hline A & Based on consistent and good-quality, patient-oriented evidence* \\
B & Based on inconsistent or limited-quality patient-oriented evidence* \\
B & Based on consensus, usual practice, opinion, or case series
\end{tabular}

Adapted from Ebell et al. ${ }^{22}$

*Patient-oriented evidence measures outcomes that matter to patients, such as morbidity, mortality, symptom improvement, and quality of life. Measures of disease activity or surrogate outcomes may or may not matter to the patient.

MA, meta-analysis; RCT, randomized controlled trial; SR, systematic review.

toms of pain and weakness can reliably be related to statin administration without an increase in CK. Despite this, there is clear evidence from a blinded biopsy study of slight but consistent damage to myocyte structural integrity in asymptomatic subjects taking statins. ${ }^{28} \mathrm{CK}$ elevation is more common among exercising people who are taking statins, ${ }^{29}$ but an increase in the enzyme is not a consistent feature of symptomatic statin-induced myopathy.

Ubiquinone, or coenzyme Q10, is produced via the cholesterol metabolic pathway, and concentra- tions are reduced by statin administration. ${ }^{30}$ It is involved in electron transport in mitochondria, and deficiency could impair mitochondrial energy metabolism in muscle, ${ }^{31}$ although evidence of this is conflicting. ${ }^{32}$ Interference in this pathway can also destabilize muscle membranes during activity. ${ }^{33}$

\section{Impact of Statin Myopathy in Exercising Adults}

Statin-related adverse effects are reported to be as low as $1 \%$ to $5 \%^{34,35}$ in the large RCTs examining drug effects on CVD events and mortality. Some of these trials have excluded up to $30 \%$ of participants

Table 2. Definitions of Muscle Syndromes

\begin{tabular}{|c|c|c|c|c|}
\hline & Myopathy & Myalgia & Myositis & Rhabdomyolysis \\
\hline $\begin{array}{l}\text { Canadian Working } \\
\text { Group }^{23}\end{array}$ & $\begin{array}{l}\text { General term for } \\
\text { muscle events }\end{array}$ & $\begin{array}{l}\text { Normal CK } \\
\text { Aching or weakness }\end{array}$ & $\begin{array}{l}\text { CK more than } \\
\text { the ULN } \\
\text { Aching or } \\
\text { weakness }\end{array}$ & $\begin{array}{l}\text { Aching or weakness } \\
\text { CK > } 10 \times \text { ULN } \\
\pm \text { Renal dysfunction }\end{array}$ \\
\hline $\begin{array}{l}\text { NLA Muscle Safety } \\
\text { Task Force }\end{array}$ & $\begin{array}{l}\text { Spectrum of muscle } \\
\text { events }\end{array}$ & $\begin{array}{l}\text { Muscle soreness, stiffness, } \\
\text { cramps, tenderness }\end{array}$ & $\begin{array}{l}\text { Muscle } \\
\text { inflammation }\end{array}$ & $\begin{array}{l}\mathrm{CK}>3 \times \mathrm{ULN} \text { with myoglobinuria } \\
\text { or acute renal failure }\end{array}$ \\
\hline $\begin{array}{l}\text { ACC/AHA/NHLBI } \\
\text { Clinical } \\
\text { Advisory }^{25}\end{array}$ & $\begin{array}{l}\text { General term for } \\
\text { muscle events }\end{array}$ & $\begin{array}{l}\text { Normal CK } \\
\text { Aching or weakness }\end{array}$ & $\begin{array}{l}\text { CK more than } \\
\text { the ULN } \\
\text { Aching or } \\
\text { weakness }\end{array}$ & $\begin{array}{l}\text { Aching or weakness } \\
\text { Marked CK elevation } \\
+ \text { Elevated creatinine } \\
+ \text { Urine myoglobin }\end{array}$ \\
\hline
\end{tabular}

ACC, American College of Cardiology; AHA, American Heart Association; CK, creatine kinase; NHLBI, National Heart Lung and Blood Institute; NLA, National Lipid Association; ULN, upper limit of normal. 
in the prerandomization run-in phase, some of whom may have had muscular symptoms. ${ }^{16}$ The quality of reporting of myalgia in these trials also is highly variable. ${ }^{36}$ There has not been much difference in muscle symptomatology reported between subjects and controls in large RCTs. ${ }^{37,38}$ There may be a tendency to attribute background muscular symptoms to the medication, be it active statin or placebo. This so-called nocebo effect ${ }^{39}$ attributes harm to the inactive intervention. With such a large component of similar symptoms present among the controls, it is challenging to demonstrate adverse effects of the statin because the signal can be overcome by the noise, so to speak.

Pain incidence seems to be higher in observational studies. More recent studies specifically targeting statin myalgia at a high dose are the Prediction du Risque Musculaire en Observationnel $(\mathrm{PRIMO})^{18}$ and The Effect of Statins on Skeletal Muscle Function and Performance (STOMP) ${ }^{40}$ studies. The former is a longitudinal observational examination of 8000 hyperlipidemic patients taking statins, $10.5 \%$ of whom reported myalgia (number needed to harm, 26). The STOMP study was an RCT showing a $9.4 \%$ incidence of reproducible myalgia with statin treatment, approximately double the frequency in the control group. A meta-analysis of high-quality prospective, observational studies ${ }^{41}$ found an odds ratio of 2.3 for muscle symptoms with a statin over placebo. A review of registry data and observational studies reports myopathy ranging from $7 \%$ to $29 \% .^{42}$

True statin-related symptoms are usually generalized and symmetrical, characterized by aching, pain, tenderness, or cramping. There may be muscular weakness. ${ }^{42}$ Regardless of the type of study, the incidence of severe myopathy marked by increased CK- exceeding 10 times the normal value-or of rhabdomyolisis is low (probably $<0.1 \%){ }^{18}$

Milder muscular symptoms may be sufficient to give the patient a compelling reason either to stop the medication or to become less physically active. A number of studies have examined the relationship of statin medication to a change in PA status. Sinzinger and O'Grady, ${ }^{43}$ in a case series of 22 young elite athletes with familial hypercholesterolemia, found that $80 \%$ of them were unable to tolerate a statin at any dose while maintaining their incident activity level. Bruckert et $\mathrm{al}^{18}{ }^{18}$ in an observational cross-sectional study of 8000 unselected patients taking high-dose statins, noted muscular symptoms in $10.5 \%$ of subjects, $38 \%$ of whom were unable to tolerate a moderate level of PA. Lee et $\mathrm{al}^{44}$ in a 7.2-year prospective cohort study of 8000 men over 65 years of age, found that subjects taking statins had a $10 \%$ decline in PA and displayed more sedentary behavior compared with controls. New statin users showed the most rapid decline in activity. An RCT examining 420 healthy, statin-naive adults showed a significant increase in $\mathrm{CK}$ and myalgia after 6 months of statin administration. ${ }^{40}$ PA status in younger subjects was well preserved, but the group over 55 years old showed a significant decline compared with controls. On the other hand, Williams and Thompson, ${ }^{45}$ in a prospective cohort study involving 78,000 statin-naive runners and walkers followed for 7.2 years, found a reduction in activity among all subjects with hypercholesterolemia, whether taking statins or not. It was postulated that this may represent reverse causality, suggesting that inactivity might lead to high lipid values, which in turn lead to an indication for statin treatment. Panza et $\mathrm{al},{ }^{46}$ in an RCT involving 418 statin-naive adults showed a reduction in PA over 6 months that was equal in those randomized to statins and in controls. This was true at all activity levels, but there were very few subjects in this trial with high levels of activity. These and other studies relating statin administration to PA levels are summarized in Table 3.

These studies leave room for optimism. While the majority of subjects given medication may reduce PA levels over time, this does not seem to be an outcome specific to statins. Caution with statin administration might, however, be appropriate in those engaging in high levels of exercise, those taking high-dose statins, and the elderly. Any muscular complaint following statin administration should be evaluated, and an attempt to mitigate symptoms should be considered given the clear benefits of medication demonstrable at all levels of PA.

\section{Mitigation of Statin Myopathy}

As indications for statins become more liberal, those who regularly exercise become candidates for therapy simply based on age and accumulation of modest risk. ${ }^{54} \mathrm{CK}$ concentrations in these people are frequently elevated. While CK concentrations can indicate muscle damage, they are not reliable as an indicator of myopathy. ${ }^{27}$ Values up to 10 times 


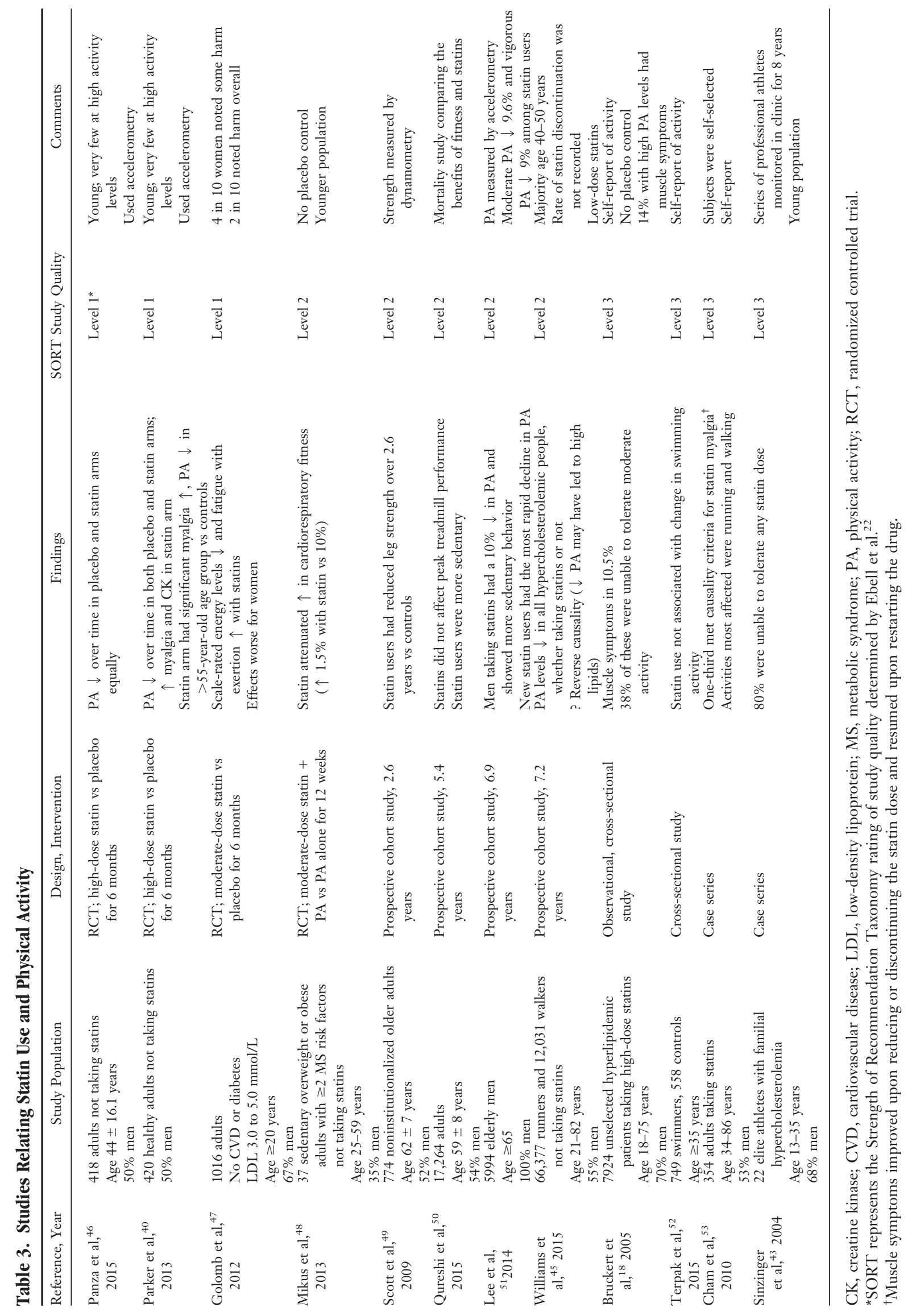


the upper limit of normal can be present without symptoms and do not warrant statin discontinuation. ${ }^{55}$ It is recommended that CK concentrations exceeding this should, in the absence of an alternative explanation, trigger discontinuation. ${ }^{56} \mathrm{CK}$ concentrations tend to be chronically elevated in those who habitually exercise and have been reported to be as high as 90 times the upper limit of normal in ultramarathoners. ${ }^{55}$ For this reason it is probably wise to obtain a baseline CK value before starting statin therapy in those with a high level of activity to properly assign a source for the enzyme elevation. ${ }^{16}$

Since the addition of statins can contribute significant further reduction in cardiovascular risk in exercising adults, a number of suggested strategies facilitate the use of medication if it is the preferred treatment plan:

\section{Ensure that a stable and continuing exercise program} is established before introducing statins. Myopathy is most common upon first starting an activity program. $^{57}$ Regular prior exercise protects against statin myopathy. ${ }^{58,59}$

2. Reduce statin potency. A large case series suggests this may be effective. ${ }^{53}$ Some suggest the use of a low dose of a more potent statin. ${ }^{36}$ The only existing RCT comparing myalgia at high and low doses of statins actually showed no difference. ${ }^{60}$ Since there is no clinical trial-based evidence for an additional benefit of high-dose statins against mortality in primary prevention, ${ }^{61}$ and since no study has established valid low-density lipoprotein targets, ${ }^{1}$ it would seem reasonable to be content with a low dose if a statin is to be used.

3. Reduce dosing frequency. Using a longer-duration preparation such as rosuvastatin 5 to $10 \mathrm{mg}$ once weekly $^{62}$ or twice a week ${ }^{63}$ has been effective in reducing myalgia. CVD outcomes from the use of this strategy after 8 years do not show significant survival benefit thus far. ${ }^{64}$

4. Change the statin preparation. A number of studies suggest that fluvastatin is least likely to cause myopathic symptoms. ${ }^{18,35}$ This may be because of its low lipophilicity, high hepatic first-pass metabolism, and high protein binding, along with the availability of a slow-release preparation. ${ }^{35}$ It has the lowest incidence of rhabdomyolysis. ${ }^{34}$ A blinded randomized trial of fluvastatin XL, ezetimibe, and a combination of the 2 showed the lowest myalgia incidence to occur with the combination. ${ }^{65}$ There was, unfortunately, no placebo control. There is evidence for improved cardiovascular outcomes with a statin/ ezetimibe combination. ${ }^{66}$

5. Vitamin D deficiency. Vitamin D deficiency can produce myalgia similar to statin myopathy. ${ }^{67}$ Observational evidence from a meta-analysis has associated the $2 .^{68}$ The best prospective cohort study suggests that vitamin D repletion can improve symptoms in $88 \%$ of statin-intolerant patients at 6 months. ${ }^{69}$ No RCTs are available. This is a harmless intervention but requires expensive testing and follow-up, and it is based on conflicting and low-quality evidence.

6. Coenzyme Q10 replacement. Statin therapy leads to low coenzyme Q10 levels. Unfortunately, a recent meta-analysis of 6 RCTs suggests no advantage to coenzyme Q10 replacement over placebo. ${ }^{70}$ Available supplements are not harmful, but can be expensive.

7. Alternative drugs. Niacin and fibrates have been shown to be effective when used alone to prevent $\mathrm{CVD},{ }^{71,72}$ but they have not been exclusively studied in primary prevention. Both have been associated with myopathy. ${ }^{25,73}$ Ezetimibe has no myopathic effect, based on a systematic review. ${ }^{74}$ In combination with colesevelam it has reduced myopathy in statin-intolerant patients. ${ }^{36}$ Ezetimibe alone currently has no evidence for improved cardiovascular outcomes. ${ }^{75}$

8. New drugs. PCSK9 inhibitors have recently become available, and phase II trials have suggested low rates of myalgia. The highest quality published study of alirocumab showed a myalgia rate of $5.4 \%$ versus $2.9 \%$ for placebo. ${ }^{76}$ Event rates for this finding were low, but the difference was significant. It is probably too early to present this drug class as a alternative to statins for this indication.

A summary algorithm in presented in Figure 1. There is a reasonable chance for success in reversing the considerable nocebo response to statin administration; however, if manipulating medications interferes with either the ability or motivation to continue PA, alternatives should be discussed with the patient. Physical inactivity should not become a prerequisite for successful statin treatment. Exercise is among the most powerful interventions in the primary prevention of CVD. ${ }^{78}$ 
Figure 1. Management of statin myopathy in exercising adults. *Lowers low-density lipoprotein (no evidence of cardiovascular disease event reduction ${ }^{109}$ ). CK, creatine kinase; ULN, upper limit of normal.

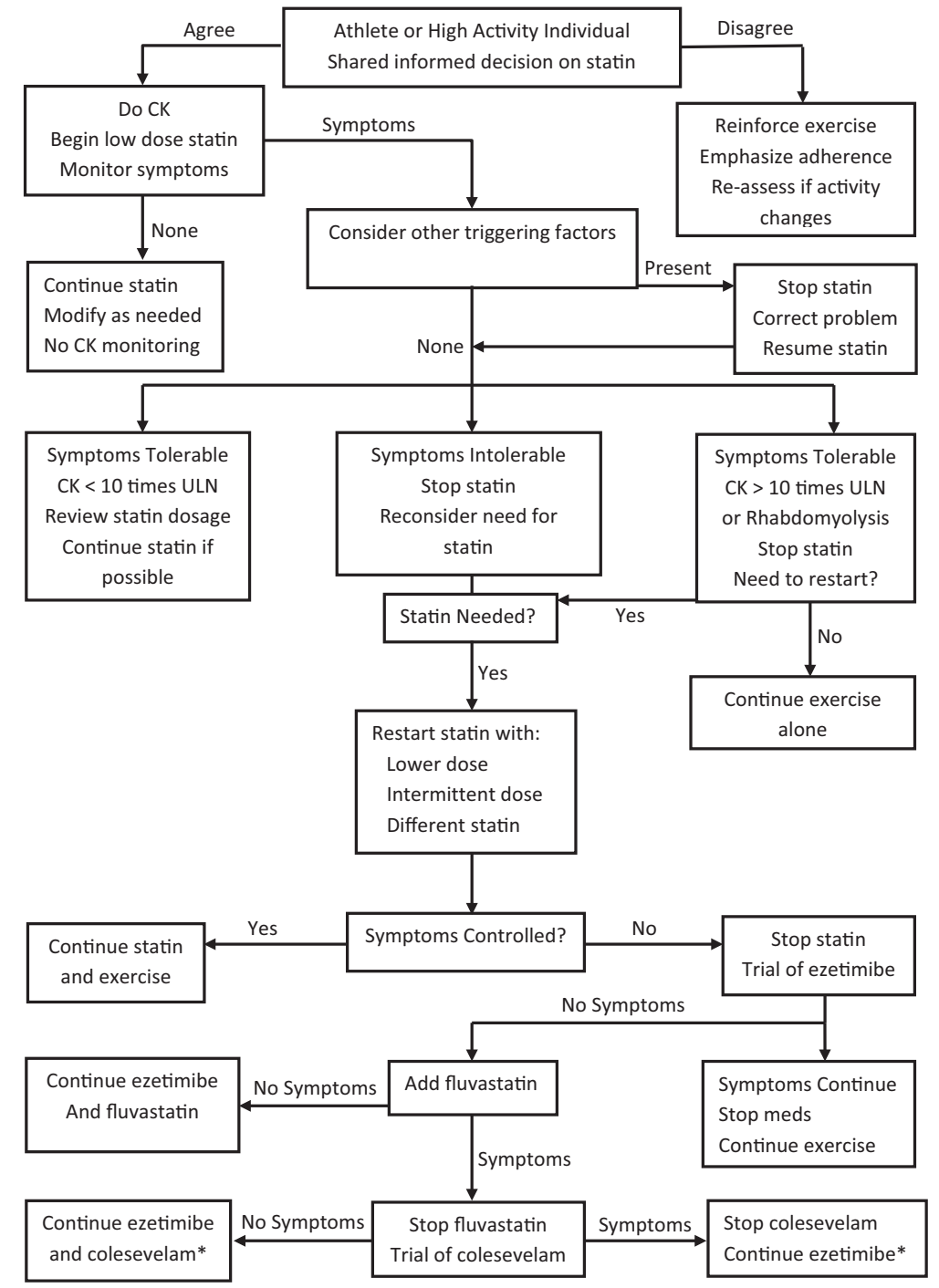

\section{Comparing the Benefits of Drug or Exercise Interventions Used Alone}

The primary prevention population without known CVD comprises a significant portion of habitual exercisers and athletes. Where a statin indication exists, there is established benefit of a combination of exercise and medication against mortality, even at high levels of activity ${ }^{21,79}$. If the addition of a statin is followed by increased muscle symptoms and attempts at mitigation fail, there may need to be a choice between modalities. A comparison of the benefits of statins and exercise in primary prevention is therefore appropriate.

Of the many large placebo-controlled statin trials, only 4 examined the primary prevention population as the sole focus. ${ }^{80-83}$ The meta-analyses of statins in primary prevention are summarized in Table 4. Some of these analyses contained trials populated with up to $20 \%$ of patients in secondary prevention. The presence of some subjects with established disease may have made estimates of statin benefit overly optimistic.

Generally, statins reduce CVD events more than all-cause mortality in primary prevention. Cardiovascular events are reduced by $20 \%$ to $40 \%,{ }^{84,86,89-91}$ with a number needed to treat between $56^{90}$ and $77^{91}$ for men and women. Benefit against all-cause mortality cannot always be demonstrated because of the small numbers of events in this population. In studies showing a benefit, ${ }^{90,91}$ the number needed to treat is much higher: between $96^{90}$ and $167 .{ }^{91} \mathrm{~A}$ benefit against mortality 
Table 4. Meta-Analyses: Statin Treatment Effects in Primary Prevention

\begin{tabular}{|c|c|c|c|c|c|}
\hline Meta-analyses & $\begin{array}{l}\text { Duration } \\
\text { (Years) }\end{array}$ & $\begin{array}{c}\text { Coronary } \\
\text { Events (HR) }\end{array}$ & $\begin{array}{c}\text { Total CVD } \\
\text { Events (HR) }\end{array}$ & $\begin{array}{l}\text { CV Mortality } \\
\text { (HR) }\end{array}$ & $\begin{array}{c}\text { All-Cause } \\
\text { Mortality (HR) }\end{array}$ \\
\hline Thavendiranathan et al, ${ }^{84} 2006$ & 4.3 & $0.78(\mathrm{NNT}, 60)$ & & NS & NS \\
\hline Mills et al, ${ }^{85} 2008$ & $1.8-5.2$ & 0.85 & & 0.89 & 0.93 \\
\hline Petretta et $\mathrm{al}^{86}{ }^{86} 2010$ & 3.9 & $\begin{array}{l}\text { Men: } 0.59 \\
\text { Women: NS }\end{array}$ & & & $\begin{array}{l}\text { Men: NS } \\
\text { Women: NS }\end{array}$ \\
\hline Bruckert et al, ${ }^{18} 2005$ & 4.1 & $0.70(\mathrm{NNT}, 77)$ & & & $0.88(\mathrm{NNT}, 167)$ \\
\hline Ray et $\mathrm{al},{ }^{87} 2010$ & 3.7 & & & & NS \\
\hline Mora et $\mathrm{al}^{88} 2010$ & Not stated & & Women: 0.63 & & Women: NS \\
\hline Kostis et $\mathrm{al}^{, 89} 2012$ & 4.0 & $\begin{array}{l}\text { Men: } 0.73 \\
\text { Women: } 0.85\end{array}$ & & & $\begin{array}{l}\text { Men: NS } \\
\text { Women: } 0.87\end{array}$ \\
\hline Savarese et $\mathrm{al}^{6}{ }^{6} 2013$ & 3.5 & 0.61 & & NS & NS \\
\hline Taylor et al,,$^{90} 2013$ & $1-5.3$ & 0.73 & & $0.65(\mathrm{NNT}, 56)$ & 0.86 (NNT, 96) \\
\hline
\end{tabular}

CV, cardiovascular; CVD, cardiovascular disease; HR, hazard ratio; NNT, number needed to treat; NS, not significant.

for women alone has been shown, ${ }^{89}$ but this is not a uniform finding. ${ }^{86,88}$ There is limited evidence that statins can reduce CVD events in elderly patients, ${ }^{6}$ but there is no benefit against mortality, and overall treatment in this age group remains controversial. Several meta-analyses provide evidence that high-dose statin therapy, as opposed to moderate doses, provides additional protection against cardiovascular events, but not all-cause mortality, in secondary prevention, ${ }^{85,92,93}$ but no such benefit has been found in primary prevention. ${ }^{61}$

The benefits of exercise extend equally to reductions in CVD and mortality, with a consistent dose response (Table 5). Variable but predictable risk reduction occured in primary care meta-analyses, with estimates ranging from $11 \%$ to $57 \%$. The greatest benefit is reported in subjects evaluated by fitness testing or accelerometry rather than by selfreport. $^{21,95}$ The tendency to overestimate PA leads to the underestimation of the exercise effect. This trend is well illustrated in the 2009 Canadian Physical Activity Survey, where $52.5 \%$ of adults reported undertaking moderate exercise. Accelerometry data showed that the true moderate activity level in this population was only $15 \% .^{98}$

Studies of exercise in primary prevention use prospective cohorts and cannot prove causation, but the findings are remarkably consistent, and the magnitude of benefit seems to be equivalent to that of statins. Moderate activity can give the same protection against mortality as statins when applied to

Table 5. Exercise Benefit in Primary Prevention: Meta-analyses of Prospective Cohort Studies

\begin{tabular}{|c|c|c|c|c|}
\hline Authors & $\begin{array}{l}\text { Time Interval } \\
\text { (Years) }\end{array}$ & $\begin{array}{c}\text { Moderate } \\
\text { Exercise (HR) }\end{array}$ & $\begin{array}{c}\text { Vigorous } \\
\text { Exercise (HR) }\end{array}$ & $\begin{array}{c}\text { Pooled Exercise (HR) } \\
\text { (Data Source) }\end{array}$ \\
\hline \multicolumn{5}{|l|}{ Mortality studies } \\
\hline Hamer and Chida, ${ }^{20} 2008$ & $4-31$ & 0.68 & & \\
\hline Löllgen et al, ${ }^{94} 2009$ & $5-26$ & $\begin{array}{l}\text { Men: } 0.81 \\
\text { Women: } 0.76\end{array}$ & $\begin{array}{l}\text { Men: } 0.78 \\
\text { Women: } 0.69\end{array}$ & \\
\hline Nocon et al, ${ }^{95} 2008$ & $4-20$ & & & $\begin{array}{l}\text { Overall: } 0.67 \text { (fitness test: } \\
0.59 \text {; self-report: } 0.71 \text { ) }\end{array}$ \\
\hline \multicolumn{5}{|l|}{ Cardiovascular event studies } \\
\hline Sofi et $a{ }^{19}{ }^{19} 2008$ & $4-25$ & 0.88 & 0.73 & \\
\hline Li and Siegrist, ${ }^{96} 2012$ & $>5$ & 0.89 & 0.76 & \\
\hline Sattelmair et al, ${ }^{97} 2011$ & No record & 0.86 & 0.80 & \\
\hline Hamer and Chida, 2008 & 4-31 & 0.69 & & \\
\hline Nocon et al, ${ }^{95} 2008$ & $4-20$ & & & $\begin{array}{l}\text { Overall: } 0.65 \text { (fitness test: } \\
0.43 \text {; self-report: } 0.70 \text { ) }\end{array}$ \\
\hline
\end{tabular}

HR, hazard ratio. 
a sedentary population. ${ }^{21}$ Vigorous activity can produce a relative risk reduction as high as $60 \% .^{21}$ Meta-analyses that compare exercise with statins for secondary prevention show a comparable effect. $^{99}$

PA may actually be superior to drug therapy in some respects:

1. In addition to comparable CVD event reduction, there is a consistent benefit against mortality in primary prevention, which is less apparent for statins.

2. Exercise benefit may be better for women than men. ${ }^{94,95}$ The benefits of statins for women has been more difficult to demonstrate.

3. There is benefit in the elderly ${ }^{100}$; this is still controversial for statins.

4. There is long-term evidence of the benefits of exercise. ${ }^{101}$ There are no long-term studies of statins, ${ }^{102,103}$ but follow-up beyond 10 years in a few large trials does show continued benefit. ${ }^{104}$

5. Exercise can delay or prevent diabetes onset. ${ }^{105}$ Statins modestly increase incidence. ${ }^{106}$

6. Higher exercise levels are associated with reduced levels of obesity. ${ }^{107}$ Statins have no influence on body mass index.

7. Exercise is associated with improved quality of life, ${ }^{108}$ which is not demonstrated with statin therapy.

While a combination of PA and drug therapy may be preferable in high-risk patients, ${ }^{21,46}$ exercise can provide a satisfactory alternative if patients are unable or unwilling to adhere to statin therapy.

\section{Discussion}

The highest-quality evidence found in this review suggests that, despite being at higher risk for myalgia, the majority of exercising adults are likely to see little impact of statin therapy on exercise intensity or duration. ${ }^{46}$ It is possible, however, that the significant nocebo effect-an adverse effect from the actual administration of a pill- has some detrimental effect on these parameters. There is reason for concern, based on lower levels evidence, that statins may adversely affect PA levels in highperformance athletes and in the elderly. In addition, high-dose statins are more likely to influence activity levels, but they afford no additional benefit over lower doses in preventing events in primary care.

This review found 1 publication examining the primary prevention literature regarding the impact of statin therapy on exercising adults. ${ }^{109}$ This was an editorial referencing an observational study, ${ }^{45}$ which related activity reduction to cholesterol levels rather than to statin administration. Reverse causality was suggested: inactivity led to high cholesterol, which triggered a statin prescription. No studies were found directly comparing PA and drug therapy interventions in the reduction of CVD events and mortality in this population. The finding of the relative equivalence of the 2 interventions is in line with meta-analyses done in secondary prevention by $\mathrm{Naci}$ and Ioannidis, ${ }^{99}$ which found them to be statistically equivalent.

\section{Limitations}

This investigation follows 3 separate lines of enquiry and attempts to draw them together to form conclusions that may be useful to generalists. It is a traditional review rather than a systematic review. Selection bias may be a risk.

The review shares the shortcomings of the existing evidence. Much of the exercise literature is observational and self-reported. Much of the statin myalgia data are poorly reported, even in the many otherwise well-done RCTs. When observational studies are the best evidence available, they can suggest only association, not causality.

\section{Future Directions}

There is a need for a large RCT of statin tolerance in both statin-naive high-performance athletes and in the elderly population, looking at drug adherence and exercise performance outcomes. Such a trial will probably be difficult to design for the inclusion of athletes, because these subjects are likely to be intolerant of any intervention that might detract from exercise performance. The statin intervention could be low dose, since there is little evidence for any benefits of high-dose therapy in primary prevention.

\section{Conclusions}

Conclusions and levels of evidence are outlined in Table 6. Statin-induced myopathy is more prominent among exercising adults, but many people taking statins are able to maintain their desired 


\begin{tabular}{|c|c|c|}
\hline Conclusion & $\begin{array}{c}\text { SORT } \\
\text { Categorization }\end{array}$ & References \\
\hline Myopathy is a significant adverse outcome of exposure to statins. & A & 40 \\
\hline Addition of statins in exercising adults significantly increases myopathy risk. & B & 18 \\
\hline \multicolumn{3}{|l|}{ Addition of statins may present special risk for reduction in physical activity in: } \\
\hline Very high levels of activity & $\mathrm{C}$ & 43 \\
\hline The elderly & $\mathrm{B}$ & $40,44,49$ \\
\hline High-dose statin therapy & $\mathrm{B}$ & 18 \\
\hline $\begin{array}{l}\text { Statins added to exercise can provide additional protection against } \\
\text { cardiovascular events and mortality. }\end{array}$ & B & 21 \\
\hline A stable level of physical activity should be established before starting a statin. & $\mathrm{B}$ & 58,59 \\
\hline $\begin{array}{l}\text { If statins are used, low doses can provide similar protection to high doses in } \\
\text { primary prevention. }\end{array}$ & $\mathrm{B}$ & 60,61 \\
\hline $\begin{array}{l}\text { Fluvastatin may be the least myotoxic of the statins and the least likely to cause } \\
\text { myalgia with exercise. }\end{array}$ & $\mathrm{B}$ & 18,35 \\
\hline $\begin{array}{l}\text { Ezetimibe and colesevelam do not cause myopathy and may be useful in } \\
\text { combination or when added to a statin. }\end{array}$ & B & 82,86 \\
\hline $\begin{array}{l}\text { Other measures to improve statin tolerance may be useful, but evidence is of } \\
\text { low quality and confounded by a considerable nocebo effect. }\end{array}$ & $\mathrm{C}$ & $53,62,63,69,70$ \\
\hline $\begin{array}{l}\text { If a choice needs to be made between drug and exercise interventions, } \\
\text { continued exercise is the better option. }\end{array}$ & B & 21 \\
\hline
\end{tabular}

SORT, Strength of Recommendation Taxonomy. ${ }^{22}$

level of activity. People at higher risk for symptoms include high-performance athletes, the elderly, and those taking high-dose statins.

Some strategies may increase statin tolerance based on low to moderate levels of evidence. Whether these strategies have a real benefit or whether they simply blunt the influence of the nocebo effect, it is usually possible to use these measures successfully to improve statin tolerability. If this is not possible, a robust and lifelong exercise habit is probably an adequate alternative to statin therapy in the primary prevention of cardiovascular events and mortality.

\section{References}

1. Stone NJ, Robinson JG, Lichtenstein AH, et al; American College of Cardiology/American Heart Association Task Force on Practice Guidelines. 2013 ACC/AHA guideline on the treatment of blood cholesterol to reduce atherosclerotic cardiovascular risk in adults: a report of the American College of Cardiology/American Heart Association Task Force on Practice Guidelines. J Am Coll Cardiol 2014;63(25 Pt B):2889-934.

2. Downs JR, O'Malley PG. Management of dyslipidemia for cardiovascular disease risk reduction: synopsis of the 2014 U.S. Department of Veterans Affairs and U.S. Department of Defense Clinical Practice Guideline. Ann Intern Med 2015;163: 291-7.
3. Anderson TJ, Grégoire J, Hegele RA, et al. 2012 Update of the Canadian Cardiovascular Society guidelines for the diagnosis and treatment of dyslipidemia for the prevention of cardiovascular disease in the adult. Can J Cardiol 2013;29:15167.

4. Han BH, Weinberger Y, Sutin D. Statinopause. J Gen Intern Med 2014;29:1702-6.

5. Mihaylova B, Emberson J, Blackwell L, et al. The effects of lowering LDL cholesterol with statin therapy in people at low risk of vascular disease: meta-analysis of individual data from 27 randomised trials. Lancet 2012;380:581-90.

6. Savarese G, Gotto AM, Paolillo S, et al. Benefits of statins in elderly subjects without established cardiovascular disease: a meta-analysis. J Am Coll Cardiol 2013;62:2090-9.

7. Afilalo J, Duque G, Steele R, Jukema JW, de Craen AJM, Eisenberg MJ. Statins for secondary prevention in elderly patients: a hierarchical Bayesian meta-analysis. J Am Coll Cardiol 2008;51:37-45.

8. Soran H, Schofield JD, Durrington PN. Cholesterol, not just cardiovascular risk, is important in deciding who should receive statin treatment. Eur Heart J 2015;36:2975-83.

9. Rose G. Sick individuals and sick populations. Bull World Health Organ 2001;79:990-6.

10. Zulman DM, Vijan S, Omenn GS, Hayward RA. The relative merits of population-based and targeted prevention strategies. Milbank Q 2008;86: 557-80. 
11. Ioannidis JPA. More than a billion people taking statins? Potential implications of the new cardiovascular guidelines. JAMA 2013;94305:463-4.

12. Powers Hannley P. Move more, eat less: it's time for Americans to get serious about exercise. Am J Med 2014;127:681-4.

13. Pleis JR, Ward BW, Lucas JW. Summary health statistics for U.S. adults: National Health Interview Survey, 2009. Vital Health Stat 10 2010; 249:1207.

14. Running USA. Running USA's annual marathon report. March 23, 2014. Available from: http://www. runningusa.org/index.cfm?fuseaction $=$ news.details \& ArticleId $=332 \&$ return $T_{o}=$ annual-reports. Accessed February 18, 2016.

15. Zingg M, Rüst CA, Lepers R, Rosemann T, Knechtle B. Master runners dominate 24-h ultramarathons worldwide-a retrospective data analysis from 1998 to 2011. Extrem Physiol Med 2013;2:21.

16. Harper CR, Jacobson TA. Evidence-based management of statin myopathy. Curr Atheroscler Rep 2010;12:322-30.

17. Fernandez G, Spatz ES, Jablecki C, Phillips PS. Statin myopathy: a common dilemma not reflected in clinical trials. Cleve Clin J Med 2011;78:393403.

18. Bruckert E, Hayem G, Dejager S, Yau C, Bégaud B. Mild to moderate muscular symptoms with highdosage statin therapy in hyperlipidemic patientsthe PRIMO study. Cardiovasc Drugs Ther 2005; 19:403-14.

19. Sofi F, Capalbo A, Cesari F, Abbate R, Gensini GF. Physical activity during leisure time and primary prevention of coronary heart disease: an updated meta-analysis of cohort studies. Eur J Cardiovasc Prev Rehabil 2008;15:247-57.

20. Hamer M, Chida Y. Walking and primary prevention: a meta-analysis of prospective cohort studies. Br J Sports Med 2008;42:238-43.

21. Kokkinos PF, Faselis C, Myers J, Panagiotakos D, Doumas M. Interactive effects of fitness and statin treatment on mortality risk in veterans with dyslipidaemia: a cohort study. Lancet 2013;381:394-9.

22. Ebell MH, Siwek J, Weiss BD, et al. Strength of recommendation taxonomy (SORT): a patient-centered approach to gathering evidence in the medical literature. J Am Board Fam Pract 2004;17:59-67.

23. Mancini GBJ, Tashakkor AY, Baker S, et al. Diagnosis, prevention, and management of statin adverse effects and intolerance: Canadian working group consensus update. Can J Cardiol 2013;29: 1553-68.

24. Rosenson RS, Baker SK, Jacobson TA, Kopecky SL, Parker BA. An assessment by the Statin Muscle Safety Task Force: 2014 update. J Clin Lipidol 2014;8:S58-71.

25. Pasternak RC, Smith SC Jr, Bairey-Merz CN, Grundy SM, Cleeman JI, Lenfant C; American
College of Cardiology; American Heart Association; National Heart, Lung and Blood Institute. ACC/AHA/NHLBI clinical advisory on the use and safety of statins. Am Coll Cardiol 2002;40: 1024-8.

26. Clarkson PM, Hubal MJ. Exercise-induced muscle damage in humans. Am J Phys Med Rehabil 2002; 81(11 Suppl):S52-69.

27. Phillips PS, Haas RH, Bannykh S, et al. Statinassociated myopathy with normal creatine kinase levels. Ann Intern Med 2002;137:581-5.

28. Draeger A, Monastyrskaya K, Mohaupt M, et al. Statin therapy introduces ultrastructural damage in skeletal muscle in patients without myalgia. J Pathol 2006;210:94-102.

29. Thompson PD, Zmuda JM, Domalik LJ, Zimet RJ, Staggers J, Guyton JR. Lovastatin increases exercise-induced skeletal muscle injury. Metabolism 1997;46:1206-10.

30. Taylor BA, Lorson L, White CM, Thompson PD. A randomized trial of coenzyme Q10 in patients with confirmed statin myopathy. Atherosclerosis 2015;238:329-35.

31. Skarlovnik A, Janić M, Lunder M, Turk M, Sabovič M. Coenzyme Q10 supplementation decreases statin-related mild-to-moderate muscle symptoms: a randomized clinical study. Med Sci 2014;20: 2183-8.

32. Tomaszewski M, Stêpieñ KM, Tomaszewska J, Czuczwar SJ. Statin-induced myopathies. Pharmacol Rep 2011;63:859-66.

33. Urso ML. Changes in ubiquitin proteasome pathway gene expression in skeletal muscle with exercise and statins. Arterioscler Thromb Vasc Biol 2005; 25:2560-6.

34. Thompson PD, Clarkson P, Karas RH. Statin associated myopathy. JAMA 2003;289:1681-90.

35. Kashani A, Phillips CO, Foody JM, et al. Risks associated with statin therapy: a systematic overview of randomized clinical trials. Circulation 2006; 114:2788-197.

36. Jacobson TA. Toward "pain-free" statin prescribing: clinical algorithm for diagnosis and management of myalgia. Mayo Clin Proc 2008;83:687-700.

37. Bulbulia R, Bowman L, Wallendszus K, et al. Effects on 11-year mortality and morbidity of lowering LDL cholesterol with simvastatin for about 5 years in 20536 high-risk individuals: a randomised controlled trial. Lancet 2011;378:2013-20.

38. McClure DL, Valuck RJ, Glanz M, Hokanson JE. Systematic review and meta-analysis of clinically relevant adverse events from HMG CoA reductase inhibitor trials worldwide from 1982 to present. Pharmacoepidemiol Drug Saf 2007;16:13243.

39. Tobert JA, Newman CB. Statin tolerability: in defence of placebo-controlled trials. Eur J Prev Cardiol 2016;23:891-6. 
40. Parker BA, Capizzi JA, Grimaldi AS, et al. Effect of statins on skeletal muscle function. Circulation 2013;127:96-103.

41. Macedo A, Taylor F, Casas JP, Adler A, PrietoMerino D, Ebrahim S. Unintended effects of statins from observational studies in the general population: systematic review and meta-analysis. BMC Med 2014;12:51.

42. Stroes ES, Thompson PD, Corsini A, et al. Statinassociated muscle symptoms: impact on statin therapy-European Atherosclerosis Society Consensus Panel statement on assessment aetiology and management. Eur Heart J 2015;36:1012-22.

43. Sinzinger H, O'Grady J. Professional athletes suffering from familial hypercholesterolaemia rarely tolerate statin treatment because of muscular problems. Br J Clin Pharmacol 2004;57:525-8.

44. Lee D-C, Pate RR, Lavie CJ, Sui X, Church TS, Blair SN. Leisure-time running reduces all-cause and cardiovascular mortality risk. J Am Coll Cardiol 2014;64:472-81.

45. Williams PT, Thompson PD. Effects of statin therapy on exercise levels in participants in the National Runners' and Walkers' Health Study. Mayo Clin Proc 2015;90:1338-47.

46. Panza GA, Taylor BA, Thompson PD, et al. The effect of atorvastatin on habitual physical activity among healthy adults. Med Sci Sports Exerc 2015; 48:1-6.

47. Golomb BA, Evans MA, Dimsdale JE, White HL. Effects of statins on energy and fatigue with exertion: results from a randomized controlled trial. Arch Intern Med 2012;172:1180-2.

48. Mikus CR, Boyle LJ, Borengasser SJ, et al. Simvastatin impairs exercise training adaptations. J Am Coll Cardiol 2013;62:709-14.

49. Scott D, Blizzard L, Fell J, Jones G. Statin therapy, muscle function and falls risk in community-dwelling older adults. QJM 2009;102:625-33.

50. Qureshi WT, Keteyian SJ, Brawner CA, Dardari Z, Blaha MJ, Al-Mallah MH. Impact of statin use on cardiorespiratory fitness in multi-racial men and women: the Henry Ford Exercise Testing (FIT) Project. Int J Cardiol 2015;197:76-7.

51. Lee DS, Markwardt S, Goeres L, et al. Statins and physical activity in older men: the Osteoporotic Fractures in Men Study. JAMA Intern Med 2014; 174:1263-70.

52. Terpak K, Guthrie S, Erickson S. Statin use and self-reported swimming performance in US masters swimmers. J Sports Sci 2015;33:286-92.

53. Cham S, Evans MA, Denenberg JO, Golomb BA. Statin-associated muscle-related adverse effects: a case series of 354 patients. Pharmacotherapy 2010; 30:541-53.

54. Ridker PM, Rose L, Cook R. A proposal to incorporate trial data into a hybrid ACC/AHA algorithm for the allocation of statin therapy in primary prevention. J Am Coll Cardiol 2015;65:942-8.

55. Glueck CJ, Rawal B, Khan NA, Yeramaneni S, Goldenberg N, Wang P. Should high creatine kinase discourage the initiation or continuance of statins for the treatment of hypercholesterolemia? Metabolism 2009;58:233-8.

56. Lenz TL. Are physically active individuals taking statins at increased risk for myopathy? Am J Lifestyle Med 2009;3:287-9.

57. Semple SJ. Statin therapy, myopathy and exercise a case report. Lipids Health Dis 2012;11:40.

58. Evans WJ, Meredith CN, Cannon JG, et al. Metabolic changes following eccentric exercise in trained and untrained men. J Appl Physiol 1986;61: 1864-8.

59. Bonfim MR, Oliveira ASB, do Amaral SL, Monteiro HL. Treatment of dyslipidemia with statins and physical exercises: recent findings of skeletal muscle responses. Arq Bras Cardiol 2015;324-32.

60. Kearns AK, Bilbie CL, Clarkson PM, et al. The creatine kinase response to eccentric exercise with atorvastatin $10 \mathrm{mg}$ or $80 \mathrm{mg}$. Atherosclerosis 2008; 200:121-5.

61. Josan K, Majumdar SR, McAlister FA. The efficacy and safety of intensive statin therapy: a meta-analysis of randomized trials. CMAJ 2008;178:576-84.

62. Ruisinger JF, Backes JM, Gibson CA, Moriarty PM. Once-a-week rosuvastatin (2.5 to $20 \mathrm{mg})$ in patients with a previous statin intolerance. Am J Cardiol 2009;103:393-4.

63. Gadarla M, Kearns AK, Thompson PD. Efficacy of rosuvastatin $(5 \mathrm{mg}$ and $10 \mathrm{mg}$ ) twice a week in patients intolerant to daily statins. Am J Cardiol 2008;101:1747-8.

64. Mampuya WM, Frid D, Rocco M, et al. Treatment strategies in patients with statin intolerance: the Cleveland Clinic experience. Am Heart J 2013;166: 597-603.

65. Stein EA, Ballantyne CM, Windler E, et al. Efficacy and tolerability of fluvastatin XL $80 \mathrm{mg}$ alone, ezetimibe alone, and the combination of fluvastatin $80 \mathrm{mg}$ with ezetimibe in patients with a history of muscle-related side effects with other statins. Am J Cardiol 2008;101:480-96.

66. Cannon CP, Blazing MA, Giugliano RP, et al. Ezetimibe added to statin therapy after acute coronary syndromes. N Engl J Med 2015;372: 2387-97.

67. Lee P, Greenfield JR, Campbell LV. Vitamin D insufficiency - a novel mechanism of statin-induced myalgia? Clin Endocrinol 2009;71:154-5.

68. Michalska-Kasiczak M, Sahebkar A, Mikhailidis DP, et al; Lipid and Blood Pressure Meta-analysis Collaboration (LBPMC) Group. Analysis of vitamin D levels in patients with and without statinassociated myalgia - a systematic review and meta- 
analysis of 7 studies with 2420 patients. Int J Cardiol 2014;178:111-6.

69. Khayznikov M, Hemachrandra K, Pandit R, Kumar A, Wang P, Glueck CJ. Statin intolerance because of myalgia, myositis, myopathy or myonecrosis can in most cases be safely resolved by vitamin D supplementation. North Am J Med Sci 2015;7:86-93.

70. Banach M, Serban C, Sahebkar A, et al. Effects of coenzyme Q10 on statin-induced myopathy: a meta-analysis of randomized controlled trials. Mayo Clin Proc 2014;90:1-11.

71. Canner PL, Furberg CD, McGovern ME. Benefits of niacin in patients with versus without the metabolic syndrome and healed myocardial infarction (from the Coronary Drug Project). Am J Cardiol 2006;97:477-9.

72. Tenkanen L, Mänttäri M, Mannien V. Some coronary risk factors related to insulin resistance syndrome and treatment with gemfibrozil. Circulation 1995;92:1779-85.

73. Magarian GJ, Lucas LM, Colley C. Gemfibrozilinduced myopathy. Arch Intern Med 1991;151: 1873-4.

74. Slim H, Thompson PD. Ezetimibe-related myopathy: a systematic review. J Clin Lipidol 2008;2: 328-34.

75. Pandor A, Ara RM, Tumur I, et al. Ezetimibe monotherapy for cholesterol lowering in 2,722 people: systematic review and meta-analysis of randomized controlled trials. J Intern Med 2009;265: 568-80.

76. Robinson JG, Farnier M, Krempf M, et al. Efficacy and safety of alirocumab in reducing lipids and cardiovascular events. N Engl J Med 2015;372: 1489-99.

77. Rivers SM, Kane MP, Busch RS, Bakst G, Hamilton RA. Colesevelam hydrochloride-ezetimibe combination lipid-lowering therapy in patients with diabetes or metabolic syndrome and a history of statin intolerance. Endocr Pract 2007;13:11-6.

78. Ford ES, Bergmann MM, Kröger J, Schienkiewitz A, Weikert C, Boeing H. Healthy living is the best revenge: findings from the European Prospective Investigation Into Cancer and Nutrition - Potsdam Study. Arch Intern Med 2009;169:1355-62.

79. Opie LH. Exercise-induced myalgia may limit the cardiovascular benefits of statins. Cardiovasc Drugs Ther 2013;27:569-72.

80. Downs JR, Clearfield M, Weis S, et al. Primary prevention of acute coronary events with lovastatin in men and women with average cholesterol levels. JAMA 1998;279:1615-22.

81. Nakamura H, Arakawa K, Itakura H, et al. Primary prevention of cardiovascular disease with pravastatin in Japan (MEGA Study): a prospective randomised controlled trial. Lancet 2006;368:1155-63.

82. Ridker PM, Danielson E, Fonseca FAH, et al. Rosuvastatin to prevent vascular events in men and women with elevated c-reactive protein. N Engl J Med 2008;359:2195-207.

83. Yusuf G, Bosch J, Dagenais G, et al. Cholesterol lowering in intermediate-risk persons without cardiovascular disease. N Engl J Med 2016;374: 2021-31.

84. Thavendiranathan P, Bagai A, Brookhard MA, Choudhry NK. Primary prevention of cardiovascular diseases with statin therapy: a meta-analysis of randomized controlled trials. Arch Intern Med 2006;166:2307-13.

85. Mills EJ, Rachlis B, Wu P, Devereaux PJ, Arora P, Perri D. Primary prevention of cardiovascular mortality and events with statin treatments: a network meta-analysis involving more than 65,000 patients. J Am Coll Cardiol 2008;52:1769-81.

86. Petretta M, Costanzo P, Perronne-Filardi P, Chiariello M. Impact of gender in primary prevention of coronary heart disease with statin therapy: a meta-analysis. Int J Cardiol 2010;138:25-31.

87. Ray KK, Seshasai SRK, Erqou S, et al. Statins and all-cause mortality in high-risk primary prevention. Arch Intern Med 2010;170:1024-31.

88. Mora S, Glynn RJ, Hsia J, MacFayden JG, Genest J, Ridker P. Statins for the primary prevention of cardiovascular events in women with elevated highsensitivity c-reactive protein or dyslipidemia: results from the Justification for the Use of Statins for Prevention: an Intervention Trial Evaluating Rosuvastatin (JUPITER) and meta-analysis of women from primary prevention trials. Circulation 2010; 121:1069-77.

89. Kostis WJ, Cheng JQ, Dobrzynski JM, Cabera J, Kostis JB. Meta-analyis of statin effects in women versus men. J Am Coll Cardiol 2012;59: 572-82.

90. Taylor F, Huffman MD, Macedo AF, et al. Statins for the primary prevention of cardiovascular disease. Cochrane Database Syst 2013;(1):CD004816.

91. Brugts JJ, Yetgin T, Hoeks SE, et al. The benefits of statins in people without established cardiovascular disease but with cardiovascular risk factors: meta-analysis of randomized controlled trials. BMJ 2009;338:b2376.

92. Yan YL, Qiu B, Hu LJ, et al. Efficacy and safety evaluation of intensive statin therapy in older patients with coronary heart disease: a systematic review and meta-analysis. Eur J Clin Pharmacol 2013; 69:2001-9.

93. Cannon CP, Steinberg BA, Murphy SA, Mega JL, Braunwald E. Meta-analysis of cardiovascular outcomes trials comparing intensive versus moderate statin therapy. J Am Coll Cardiol 2006;48: $438-45$.

94. Löllgen H, Böckenhoff A, Knapp G. Physical activity and all-cause mortality: an updated metaanalysis with different intensity categories. Int J Sports Med 2009;30:213-24. 
95. Nocon M, Hiemann T, Müller-Riemenschneider F, Thalau F, Roll S, Willich S. Association of physical activity with all-cause and cardiovascular mortality: a systematic review and meta-analysis. Eur J Cardiovasc Prev Rehabil 2008;15:239-46.

96. Li J, Siegrist J. Physical activity and risk of cardiovascular disease - a meta-analysis of prospective cohort studies. Int J Environ Res Public Health 2012;9:391-407.

97. Sattelmair J, Pertman J, Kohl HW III, Haskell W, Lee I-M. Dose-response between physical activity and risk of coronary heart disease: a meta-analysis. Circulation 2011;124:789-95.

98. Colley RC, Garriguet D, Janssen I, Craig CL, Clarke J, Tremblay MS. Physical activity of Canadian adults: accelerometer results from the 2007 to 2009 Canadian Health Measures Survey. Health Rep 2011;22:7-14.

99. Naci H, Ioannidis JPA. Comparative effectiveness of exercise and drug interventions on mortality outcomes: metaepidemiological study. BMJ 2013;347: f5577.

100. Hupin D, Roche F, Gremeaux V, et al. Even a low-dose of moderate-to-vigorous physical activity reduces mortality by $22 \%$ in adults aged $\geq 60$ years: a systematic review and meta-analysis. Br J Sports Med 2015;49:1262-7.

101. Chakravarty EF, Hubert HB, Lingala VB, Fries JF. Reduced disability and mortality among ageing runners: a 21-year longitudinal study. Arch Intern Med 2008;168:1638-46.
102. Vos E, Rose CP, Biron P. Rebuttal: why statins have failed to reduce mortality in just about anybody. J Clin Lipidol 2013;7:228.

103. Tomlinson SS, Mangione KK. Potential adverse effects of statins on muscle. Phys Ther 2005;85: 459-65.

104. Soverow J, Watson K. Is there sufficient enhancement of the reduction in CVD rates after a decade of statin therapy to justify continuation? Curr Atheroscler Rep 2014;16:432.

105. Knowler WC, Barrett-Connor E, Fowler SE, et al; Diabetes Prevention Program Research Group. Reduction in the incidence of type 2 diabetes with lifestyle intervention or metformin. $\mathrm{N}$ Engl J Med 2002;346:393-403.

106. Cederberg H, Stancakova A, Yaluri N, Modi S, Kuusisto J, Laakso M. Increased risk of diabetes with statin treatment is associated with impaired insulin sensitivity and insulin secretion: a 6 year follow-up study of the METSIM cohort. Diabetologia 2015;58:1109-17.

107. Rissanen AM, Heliövaara M, Knekt P, Reunanen A, Aromaa A. Determinants of weight gain and overweight in adult Finns. Eur J Clin Nutr 1991; 45:419-30.

108. Martin CK, Church TS, Thompson AM, Earnest CP, Blair SN. Exercise dose and quality of life: a randomized controlled trial. Arch Intern Med 2009; 169:269-78.

109. Franklin BA, Lavie CJ. Impact of statins on physical activity and fitness: ally or adversary? Mayo Clin Proc 2015;90:1314-9. 